International Journal of Linguistics, Literature and Translation (IJLLT)

ISSN: 2617-0299 (Online); ISSN: 2708-0099 (Print)

DOI: $10.32996 / \mathrm{ijllt}$

Journal Homepage: www.al-kindipublisher.com/index.php/ijllt

\title{
Can Futsugo be Acceptable in Hotel Services? A Case Study of a Hotel in Bali
}

Indah Kusumarini ${ }^{1 *}$, I Wayan Simpen², Made Budiarsa ${ }^{3} \&$ I Ketut Darma Laksana ${ }^{4}$

${ }^{1}$ Politeknik Pariwisata Bali, Indonesia

${ }^{234}$ Udayana University, Indonesia

Corresponding Author: Indah Kusumarini, E-mail: indahnusabakti@gmail.com

\section{ARTICLE INFORMATION}

Received: December 08, 2020

Accepted: January 14, 2021

Volume: 4

Issue: 1

DOI: 10.32996/ijllt.2021.4.1.9

\section{KEYWORDS}

tructuralism, short story, Torres,

Mexican American, folktale

\section{ABSTRACT}

This article discusses futsugo (Japanese daily language). The aim of this research is to know whether Futsugo style can be used at hotel services. As we know that hotels are the main constituent of the hospitality industry which keep special attention to courtesy and services, so is it possible for the hotel staff to use it? Does it threaten guests' faces? The data analyzed is conversation instances between Japanese guests and hotel staff in Bali hotels. The sampling used is a random sampling technique. The sample used in the study is 10 hotels out of 73 five-star hotels in Bali. The conversation data is recorded with mobile phones by hotel staff. The total number of the hotel staff members as the subjects of this research is 15 participants. The data was conducted from May 2019 till August 2019. Brown and Levinson's (1987) politeness theory is used to analyze conversations between Japanese guests and hotel staff in Bali from the stages of arrival, familiarization, and engagement until departure. Based on data analysis, it is known that generally hotel staff use negative politeness strategies alternately with positive politeness strategies depending on the context of the speech situation. From these four those stages, it is found that Futsugo utterances are at the engagement stage. Futsugo style was used by the staff during handling guest complaints. In one dialogue, Futsugo's utterance was found in the form of question sentences without question marks, but using the rising intonation and confirmation of the guest's answer without the copula desu. According to the analysis of the conversation data, futsugo utterances are used by hotel staff and guests as a practical way of communicating. Futsugo's utterances which tend to be short are easier to catch by the ear, making it easier to handle guest complaints. If viewed from the perspective of politeness theory, this speech can still be accepted. It can be seen from the whole conversation where negative politeness strategies and positive politeness strategies are applied in one dialogue that the appearance of Futsugo's utterances is still considered acceptable and does not threaten guests' faces.

\section{Introduction}

Japan is a country with an empire background. There are nobility and commoners. The existence of differences in social strata has an impact on the emergence of language variations. These are the Keigo (respectful language) and the Futsugo (daily language). Keigo is used in formal situations. For example, in offices, weddings, communication between the sellerconsumers and other official situations. Keigo is also used on people who are meeting for the first time. On the other hand, Futsugo is used in informal situations, such as situations at home when communicating with family members, friendship, close or intimate relationships and talking to younger people. Keigo can be said to be a special form of expression used to show politeness and respect.

In Japanese society, the use of Keigo is regulated by observing social rules: (1) be polite towards people who have a higher social position, (2) be polite towards people who have power. (3) be polite to older people, and (4) be polite in formal situations, Idea (1989, pp. 223-248). In general, when they meet someone for the first time, Japanese people will choose the variety of Teinego (a

AL-KINDI CENTER FOR RESEARCH AND R. D DEVELOPMENT Your gateway to world-class research

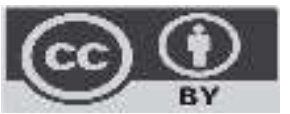

Published by Al-Kindi Center for Research and Development. Copyright (c) the author(s). This open access article is distributed under a Creative Commons Attribution (CC-BY) 4.0 license 
variety of Keigo), while they estimate the age of their interlocutor, and their social status, so they can determine what kind of language that should be used. There are three kinds of Keigo, 1) Songkeigo, 2) Kenjyougo and 3) Teineigo. Songkeigo is used to honor the addressee or the third person by exalting them including objects, family and things related to addressee or the third person. Kenjyougo is used to respect the addressee or the third person by humbling the speaker, including family, co-workers, and all things included in the internal group (uchi). Teineigo is used to respect addressee by using polite form, without any element of elevating the hearer or degrading the Speaker. Teineigo style can be said as standard respect and neutral. It is used to express formality by the speaker towards the addressee based on their relationship or situation.

Futsugo is a form of informal language used when utterance is addressed to close people such as family, friends, to people who are younger, and their position is lower than the speaker. Japanese people don't use the Keigo when talking to their family members, even though parents or grandparents-still huse futsugo. They do not raise their own family members in front of others. Therefore, how if Futsugo is used in hotel services? Is it acceptable?

We know hotel services are different from the other place services, since there are special norms in hospitality services. Each department has service standards, such as reception standards service at the reception desk, food ordering standards service in restaurants, serving food, clearing-up guest tables and others. Below is an example of the procedures for receiving guests by hotel reception staff.

1) Say hello, say welcome and offer to help

2) ask if the guest has booked a room

3) If the guest has already booked a room, check the system again

4) Guests fill out the registration form

5) Reception gives room's key and guest card

6) Say relax your life at this hotel

7) Give instructions to bellboys to escort the guest to the room as well as carry guests' luggage.

(Bagyono, 2012, p.

109)

The hospitality industry made these rules with the aim of being able to guide each staff, so that they can carry out their duties according to or close to the standards which are determined by the hotel owner. Why do hotels make standard services to guests? Service is an important thing in the hotel industry. The physical beauty of the hotel so that the service does not disappoint the guests. Guests are very important. Guests are parties who buy hotel products. As a product buyer, guests are entitled to a pleasant and satisfying service. Guest satisfaction is the main priority in the management of a hotel business. Guests already pay for comfort while staying at the hotel, so naturally guests have an expectation that is proportional to the costs that they have spent.

The hospitality industry depends on visiting guests. If there are no guests, the hotel will die. As the current conditions, with the corona outbreak hitting the world, there had been a major impact on tourists visiting Bali. It can be said that Bali tourism paralyzed due to the absence of tourist visits for almost one year.

The hotel industry physically displays luxury, beautiful buildings and facilities aimed at pampering guests, such as luxurious rooms, swimming pool comfort, beautiful gardens, beaches as well as food and beverage offerings. Services and courtesy are essential elements in the hospitality industry. By the intense competition in the hospitality industry in Bali, each hotel was trying to create an attractive appearance, on the physical and the services levels. The staff is friendly, looks good, polite and attentive to guest needs. Many hotels intent to show their uniqueness in welcoming guests, for example by attaching flowers to their ears, draping garlands, or gamelan accompaniment and so on. All of these services are intended to get a pleasant impression on the minds of guests. If guests are happy and satisfied with the services provided by the hotel, they will happily stay again, recommend to others, provide positive reviews about the hotel and of course provide positive benefits for the hotel, namely increasing the hotel's reputation in the public eye, and to attract other potential guests to stay overnight.

Service at the hotel also includes verbal elements. Communication skills are important in serving guests. According to Harun (1998, p. 77), service language is a skill that must be mastered by tourism actors, such as: (1) how to greet guests, 2) how to ask 
and provide the necessary information, 3) how to respond to guest question, 4) how to use body movement, 6) how to deal with guests' complaints. The relationship between guests and tourism is an asymmetrical relationship, so the host always implements formality in service including how to communicate with guests. For example, when guests arrive, they will be greeted with "welcome to hotel X", and guests will be called "okyaku sama". Here, the language used is Keigo as an expression of respect from staff to guests.

Research related to services has been conducted by Merlyana (2019) with the title "Japanese Language Politeness by Indonesian Caregiver Towards the Elderly in Japan". Merlyana (2019) saw the linguistic phenomenon between caregivers and elderly patients in the domain of the elderly home environment (roojin hoomu) in Japan. Merlyana's research results show that Indonesian caregivers use Futsugo utterances more with Japanese elderly, such as the below speech data.

Utterance:

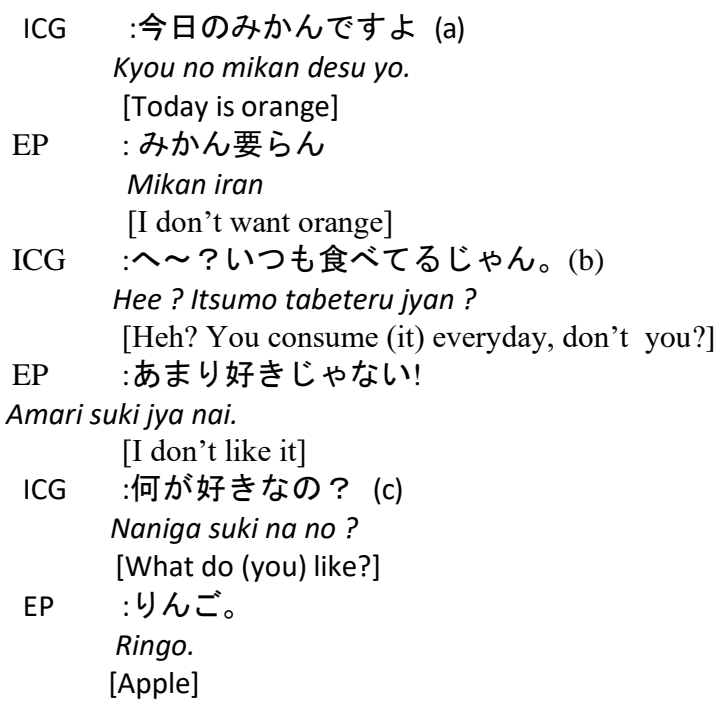

At the beginning of the conversation, the Caregiver uses the formal Teineigo style. However, in speech $(b-c)$ the Caregiver uses futsugo style. The futsugo style is one of the characteristics of a positive politeness strategy. The use of futsugo is acceptable if the speaker has more power than the addressee. However, this concept cannot be applied in caregiver services for the elderly that have the power. Based on the results of the questionnaire survey, it is found that the Caregiver uses the futsugo to show empathy, tolerance and to reduce the distance between them so that the elderly do not feel awkward, including matters of toilet, changing pampers, clothes and so on. Merlyana's findings illustrate that Japanese service is not a necessity using the Keigo (respectful language). The domain and the party receiving the service determines what kind of language is appropriate to use.

Therefore, in this paper is going to discuss the form of futsugo, can it be accepted in hospitality services? In what conditions can staff use the futsugo? Because this study is a study of language used as a communication tool, especially in the hospitality industry, politeness theory will be used as a basis of exploring the language of guest services. Considering that the speech analyzed is Japanese spoken by hotel staff, a supporting theory is needed, namely the Japanese language variety.

\section{Literature Review}

\section{Politeness}

Politeness according to the viewpoint of Brown \& Levinson (1987) is an attitude of concern for the face, both of the speaker and the addressee. Face in this case does not mean physical appearance, but rather refers to image or self-esteem. Face is a reflection of language that is first seen in a communication event. Therefore, the face is very important; the face must be cared for, respected, and guarded. So the essence of politeness is the ability to always maintain self-respect, feelings, and honor, both of oneself and others. Brown \& Levinson (1987) distinguish between two types of "face", namely positive face, which means showing solidarity, closeness, a desire to be part of the other person. Meanwhile, negative face shows the desire not to be disturbed.

In Brown and Levinson's (1987: 74) politeness model, there are three scales to determine the high and low levels of speech politeness. The three scales were determined contextually, socially and culturally, including (1) distance: the social distance between the Speaker and Listener, the level of intimacy (2) power: the extent to which the Speaker can impose on the speech partner and (3) Rank of Imposition: how much the speaker's speech will be a burden on the listener.

How much an utterance will threaten the face of the addressee/hearers will affect the choice of the speech strategy. If it is felt 
that it does not threaten the face of the addressee, direct speaking strategies will tend to be used. On the other hand, if it is felt that the addressee/hearers will face up to them, the indirect speaking strategy will be used. Therefore, Brown \& Levinson (1987: 60) identified four politeness strategies to guard against threats. The four strategies are (1) bald-on record strategy (without strategy), (2) positive politeness strategy (familiarity strategy), (3) negative politeness strategy (formal politeness strategy), (4) off- record politeness strategy (indirect or disguised strategy).

The positive politeness strategies include: 1) paying attention to what the interlocutor needs, 2) using markers of group solidarity, fostering an optimistic attitude, 3) involving speech partners in the activities of speakers, 4) offering / promising something, 5) giving praise to speech partners, 6) avoiding mismatch, and 7) being funny. Meanwhile, negative politeness strategies include: 1) expressing indirectly, 2) using hedges or question sentences, 3) being pessimistic, 4) not burdening, 5) using the passive form, 6) apologizing, and 7) using the plural form.

\section{The Variety of Japanese}

The following paragraphs will explain explain the variety of Japanese, which has been taken from several references, such as: (1) Shin Nihongo no Kiso (1994: 76-83), (2) keigo nyuumon (Kikuchi, 1996: 23). According to these references, it is explained that Japanese has two kinds of languages, the Keigo (respectful language) and the Futsugo (daily language).

Keigo is a kind of respectful language that is intended to respect the interlocutor and the person being spoken to. Keigo consists of three kinds, 1) Sonkeigo, 2) Kenjyoogo and 3) Teineigo. Teineigo is polite speech that is used to respect addressee. Songkeigo is a speech used to elevate the interlocutor and in the third person as an expression of respect. Meanwhile, kenjyoogo is a form of humbling speakers (including the in-group) as an expression of respect towards the addressee.

\subsection{Sonkeigo (honorific language)}

Sonkeigo is a form of respect that is used to elevate the interlocutor, along with the person or the topic being talked about, including objects, circumstances and activities. For example, asking about other people's parents in the example conversation below:

Situation context:

Made asked Kaori san about her parents.

(1) Made : "Goryooshin wa ima Bali ni irassharun desu ka?" [Are your parents in Bali now?]

Kaori : Hai, Ryooshin wa ima Bali ni imasu yo

The addition of the prefix 'go' to the noun ryooshin (parent) is an attempt by speakers to raise the speech partner and objects related to the speech partner. In this case it is the parents of the speech partner.

Here are a few ways to express Songkeigo:

1. Adding prefix, "o" and "go" to nouns such as:

$\begin{array}{ll}\text { kyaku (guest) } & \rightarrow \text { o kyaku sama } \\ \text { nimotsu (luggage) } & \rightarrow \text { o nimotsu }\end{array}$

ryooshin (parent) $\rightarrow$ go ryooshin

shuppatsubi(departuredate) $\rightarrow$ go shuppatsu bi

2. Addition of suffixes, such as:

Tanaka -san (Mr. Tanaka)

Tanaka-sama (Mr. Tanaka) "sama" is higher than "san".

3. Using a special verbs of Songkeigo

Table 1: Special Verb of Songkeigo

\begin{tabular}{|l|l|l|}
\hline \multicolumn{1}{|c|}{ Masu kei } & \multicolumn{1}{c|}{ Sonkeigo } & \multicolumn{1}{c|}{ Meaning } \\
\hline ikimasu & Irrassahaimasu & go \\
\hline kimasu & Irrasshaimasu & come \\
\hline imasu & Irasshaimasu & There are (people) \\
\hline tabemasu & Meshiagarimasu & eat \\
\hline
\end{tabular}




\begin{tabular}{|l|l|l|}
\hline nomimasu & Meshiagarimasu & drink \\
\hline limasu & Ossahimasu & Say \\
\hline Shitteimasu & Gozonji desu & Tofu \\
\hline Mimasu & Goran ni narimasu & See/look \\
\hline Shimasu & Nasaimasu & To do \\
\hline Kuremasu & Kudasaimasu & Receive \\
\hline
\end{tabular}

4. Using the auxiliary verb $\sim$ reru + verbs of group 1 , $\sim$ rareru + verbs of group 2 .

Group 1 verbs, such as:

$$
\begin{array}{ll}
\text { Kaku ( write) } & \rightarrow \text { kakareru } \\
\text { Iku ( go ) } & \rightarrow \text { ikareru } \\
\text { Hanasu (speak) } & \rightarrow \text { hanasareru }
\end{array}
$$

Group 2 verbs, such as:

$$
\begin{array}{ll}
\text { Taberu ( eat) } & \rightarrow \text { taberareru } \\
\text { Miru ( see/look) } & \rightarrow \text { mirareru }
\end{array}
$$

5. Inserting verb in the form of renyookei in the pattern "o + ni naru"

$$
\begin{aligned}
& \text { Matsu (waiting) } \rightarrow \text { o machi ni naru } \\
& \text { Yomu (reading) } \rightarrow \text { o yomi ni naru }
\end{aligned}
$$

6. Using a special noun as a greeting (pronoun), placed behind the name of the interlocutor and the third person, such as; okyakusama (tourist / guest), Sensei (teacher, doctor), shachoo (boss, director), kachoo (department head).

7. Respect for requests, pattern "o + form -masu + kudasai"

Robii de omachi kudasai (please wait in the lobby)

Doozo ohairi kudasai (please enter)

\subsection{Kenjyoogo (humility or humble language)}

Kenjyoogo is a form of respect of the speech partners or the people who are spoken to in a way the speaker uses selfdeprecating words. Likewise, people who are on the speakers' side are also humiliated, such as their own families, groups of coworkers themselves, associations, organizations, and sports teams. In essence, the uchi (inside group) was considered by the speaker's family so that the kenjyoogo variety was used to respect the speech partners as soto (outside group). An example can be seen in the conversation below:

\section{Situation context:}

A child receives a call from Mrs Yoshida (her mother's friend).

(2) Yoshida san: Okaasan wa irasshaimasu ka?

[ Is your mother at home?]

Child : Haha wa chotto dekaketeorimasu ga ....

[ Mother is out of the house]

"Okaasan" and "Haha" mean "mother". In data 2, Mrs. Yoshida uses the word "okaasan" as an expression of respect of the soto (outside group). Meanwhile, the child uses the word 'haha' to describe his own mother, as the uchi (inside group). Likewise, from the verb, there is an elevating expression (songkeigo) of the verb "irasshaimasu". On the other hand, the child uses " te orimasu" (kenjyoogo) as an expression of humbling his family members.

Here are a few ways to express Kenjyoogo:

1. Inserting the verb renyookei in the "o shimasu" pattern (for verbs group 1 and 2)

$$
\begin{array}{ll}
\text { Mochimasu (to bring) } & \rightarrow \text { o mochi shimasu } \\
\text { Tetsudaimasu (to help) } & \rightarrow \text { o tetsudai shimasu }
\end{array}
$$


Example : A bellboy offers to help the guests carrying their luggage-

(3) Oyakusama, onimotsu o omochishimashou ka?

[Sir, may I carry your luggage]

2. Inserting the verb renyookei in the "go $\sim$ shimasu" pattern

(for group 3 verbs)

$$
\begin{array}{ll}
\text { Annai shimasu (to guide) } & \rightarrow \text { go annai shimasu } \\
\text { Riyoo shimasu (to use) } & \rightarrow \text { go riyoo shimasu }
\end{array}
$$

Example, when a bellboy takes guests to the room.

(4) Okyakusama, oheya e go annai shimasu

[Sir / Madam, please let us take you to your room]

3. The concepts of uchi (inside group) and soto (outside group)

\begin{tabular}{|c|c|c|c|}
\hline \multicolumn{2}{|c|}{ Uchi(inside group) } & \multicolumn{2}{|c|}{ Soto(outside group) } \\
\hline kazoku & Family & Gokazoku & family \\
\hline haha & Mother & Okaasan & mother \\
\hline chichi & Father & Otoosan & father \\
\hline Ane & Big sister (female) & Oneesan & big sister \\
\hline Ani & Big brother (male) & Oniisan & big brother \\
\hline otooto & Young brother (male) & otootosan & young brother \\
\hline imooto & Young sister (female) & imootosan & young sister \\
\hline shujin & husband & Goshujin & husband \\
\hline kanai & wife & Okusan & wife \\
\hline kodomo & child & Okosan & child \\
\hline musume & boy (male) & musume san & boy \\
\hline musuko & daughter (female) & musuko san & daughter \\
\hline Tanaka & $\begin{array}{l}\text { Someone who named } \\
\text { Tanaka }\end{array}$ & Tanaka san & Mr.Tanaka \\
\hline minna & All & Mina san/sama & All of you \\
\hline $\begin{array}{l}\text { Kaisha no } \\
\text { mono }\end{array}$ & $\begin{array}{l}\text { people /fellow company } \\
\text { colleagues }\end{array}$ & Kaisha no kata & People in company \\
\hline
\end{tabular}

Table 2: The Concepts of Uchi and Soto 
4. Use a special verbs of kenjyoogo

Table 3: Special Verbs of Kenjyoogo

\begin{tabular}{|l|l|l|}
\hline Masu- kei & Kenjyoogo & meaning \\
\hline Ikimasu/kimasu/imasu & Mairimasu & Go/come/ there are \\
\hline shimasu & itashimasu & Do \\
\hline kikimasu & ukagaimasu & Listen \\
\hline tabemasu & Itadakimasu & Eat \\
\hline nomimasu & itadakimasu & Drink \\
\hline moraimasu & itadakimasu & Receive \\
\hline mimasu & Haiken shimasu & See/look \\
\hline iimasu & mooshimasu & Say \\
\hline Hoomon shimasu & ukagaimasu & Visit \\
\hline shitteimasu & Zonjite orimasu & Know \\
\hline shirimasen & zonjimasen & Do not know \\
\hline
\end{tabular}

\subsection{Teineigo ( usual formal language)}

The polite form used by Speaker to honor hearers. Teineigo is a polite way of speaking used by speakers with mutual respect or respect for each other's feelings. The use of Teineigo has nothing to do with increasing or decreasing speech. For verbs ending in $\sim$ masu. Nouns and adjectives end with copula $\sim$ desu. To show more respect (super teineigo) the copula "desu" was changed to $\sim$ de gozaimasu. For example:

(5) koko wa toire desu.

[ Here is the toilet]

If the addressee is a person who is respected, and has a higher position, such as the relationship between tourism actors and guests, then the sentence above will change to

(6) Kochira wa toire de gozaimasu.

[Here is the toilet]

The word "koko" (here) if changed to a subtle or respectful form would become "kochira". Kopula "desu" changed to "de gozaimasu".

In the ministry setting, several phrases which are Teineigo forms have their equivalent in the subtle form (super teinego). For example:

$$
\begin{array}{ll}
\text { Wakarimashita } & \rightarrow \text { kashikomarimashita (understand) } \\
\text { Irasshai } & \rightarrow \text { irasshaimase (welcome) } \\
\text { Okaerinasai } & \rightarrow \text { okaerinasaimase (welcome back) } \\
\text { Itterasshai } & \rightarrow \text { itterassahimase (have a nice day/travelling) } \\
\text { Oyasuminasai } & \rightarrow \text { oyasuminasaimase (have a good rest) }
\end{array}
$$

In choosing the variety of Keigo, several factors need to be considered, such as: the relationship between the speakers, who the other person is talking to, how close they are, the situation and the conditions. Kaneko (2014: 162) mentions that Japanese people speak politely when they meet someone for the first time, usually using Teineigo as a neutral, respectful language. Then they will choose their language after getting to know each other. Kaneko explained that there are five things that determine the choice of keigo language, namely, (1) age, (2) social position, (3) service background, (4) uchi-soto concept and (5) closeness. 


\subsection{Futsugo ( daily language)}

Futsugo is a form of informal language used when speech is addressed to people who are close, such as family members, there is no social distance, and their age and position are below the speakers. Futsugo is translated as an ordinary language, meaning that the language does not have an element of respect. Futsugo has a basic form of verb markers, or in Japanese it is called Gokan. All nouns and adjective words will end with the copula "da" which has the same function as the predicate. The following conversation is an example of using the futsugo form which is often used in informal conversations.

(7) Yuri : Ashita, gakkoo ni iku?

[are you going to school tomorrow?]

Kaori : ee, iku yo

[Yes, I go]

Yuri and Kaori are friends, so they use a variety of informal languages. It seen from the futsukei form of the verb, the basic verb "iku" (go) and the answer "ee" is the informal form of "hai" (yes).

\section{Tabel 4: The dictonary entry( Basic Form of Verb)}

\begin{tabular}{|l|l|l|l|}
\hline Classification of Verbs & The final syllable & Dictionary form & Equivalent in English \\
\hline Group 1 Verb & $\mathrm{u}$ & au & To meet \\
\hline & $\mathrm{tsu}$ & matsu & To wait \\
\hline & $\mathrm{ru}$ & hairu & To come in \\
\hline & $\mathrm{bu}$ & asobu playing & To read \\
\hline & $\mathrm{mu}$ & yomu & To go \\
\hline & $\mathrm{ku}$ & $\mathrm{iku}$ & To sweeming \\
\hline Group 2Verb & $\mathrm{gu}$ & oyogu & To see \\
\hline & $\mathrm{iru}$ & miru & To eat \\
\hline Group 3 Verb & eru & taberu & To come \\
\hline & kuru & kuru & To do \\
\hline
\end{tabular}

Futsugo style uses dictionary form verbs (basic verbs). Meanwhile, nouns and adjectives na (na keiyoushi) end with copula $\sim$ da. The following is an example of a sentence that ends with a $\sim$ da copula.

(8) Kore wa watashi no atarashii kaban da.

[This is my new bag]

(9) Kono ko wa genki da ne

[This child is really healthy]

(10) kono nasi goreng wa totemo oishii

[This fried rice is really delicious ]

In the sentence number 10, the adjective is not added behind as a Futsukei style. If you change to the Teineigo style, you just have to add the copula "desu". There are several sentence patterns including futsugo, for example in the form of a question sentence, but not followed by an interrogative word; spoken in an ascending tone, as an expression of a question word. For example: kore ikura? How much is this. Ima Nanji? What time is it now. If you change to Teineigo, just add the copula desu ka?

\section{Methodology}

This research is a qualitative descriptive study. the data analyzed is conversation between japanese guest and hotel staff members in Bali. The data is obtained by recording the dialogue between hotel staff and guests while performing services. The recording process is carried out by the hotel staff secretly with cellphone recording aids. The sampling used is a random sampling technique. Out of 73 five-star hotels in Bali, 10 hotels are chosen a sample in this research. These are Padma ResortLegian, Intercontinental Resort-Jimbaran, the Four Seasons- Jimbaran, Ayana-Jimbaran, Grand Ina Kuta Bali, Melia Bali- Nusa Dua, Ritz Carlton-Nusa Dua, Conrad Bali-Nusa Dua. Grand Hyatt-Nusa Dua, Alila Ubud. The hotel staff used as subjects of study totalled 15 participants. They are staff of airport representatives, bellboys, doormen, guest relation officers, receptionists and waiters or waitresses. The data was conducted from May 2019 till August 2019. These are months when a lot of Japanese tourists visit Bali. There were 17 recorded data from the arrival at the airport, arriving at the hotel, stay at the hotel, till departure. 


\section{Results and Discussion}

The data analyzed is a conversation between the guest and the staff of the Guest Relation Officer (GRO) when solving guest problems. GRO's job aside from standing by at the front desk, also performed "guest curtesy calls". This activity can be done by telephone but can also be done face to face. Guest curtecy activities are aimed at getting feedback from guests regarding staff service, guest comfort during their stay. Ensure if there is a problem or not with room services and facilities, food menus, the tranquility of the hotel environment and so on. If done face to face, GRO staff usually do it during breakfast hours. The relaxed situation at the dining table is very possible to ask for feedback from guests.

\section{Data 1.}

Topic : Warm reizooko (warm minibar)

The interactants:

GRO: 47 years old/male ( Melia Bali hotel)

Guest: 60 yeras old/male

First coming guest

The guest stays on the 3rd day

The context of the speech situation: GRO staff performs "guest courtesy tasks" towards Japanese guests who are enjoying breakfast. GRO asks the condition of the guest room by starting with asking if the guest wants to add coffee or tea drinks.

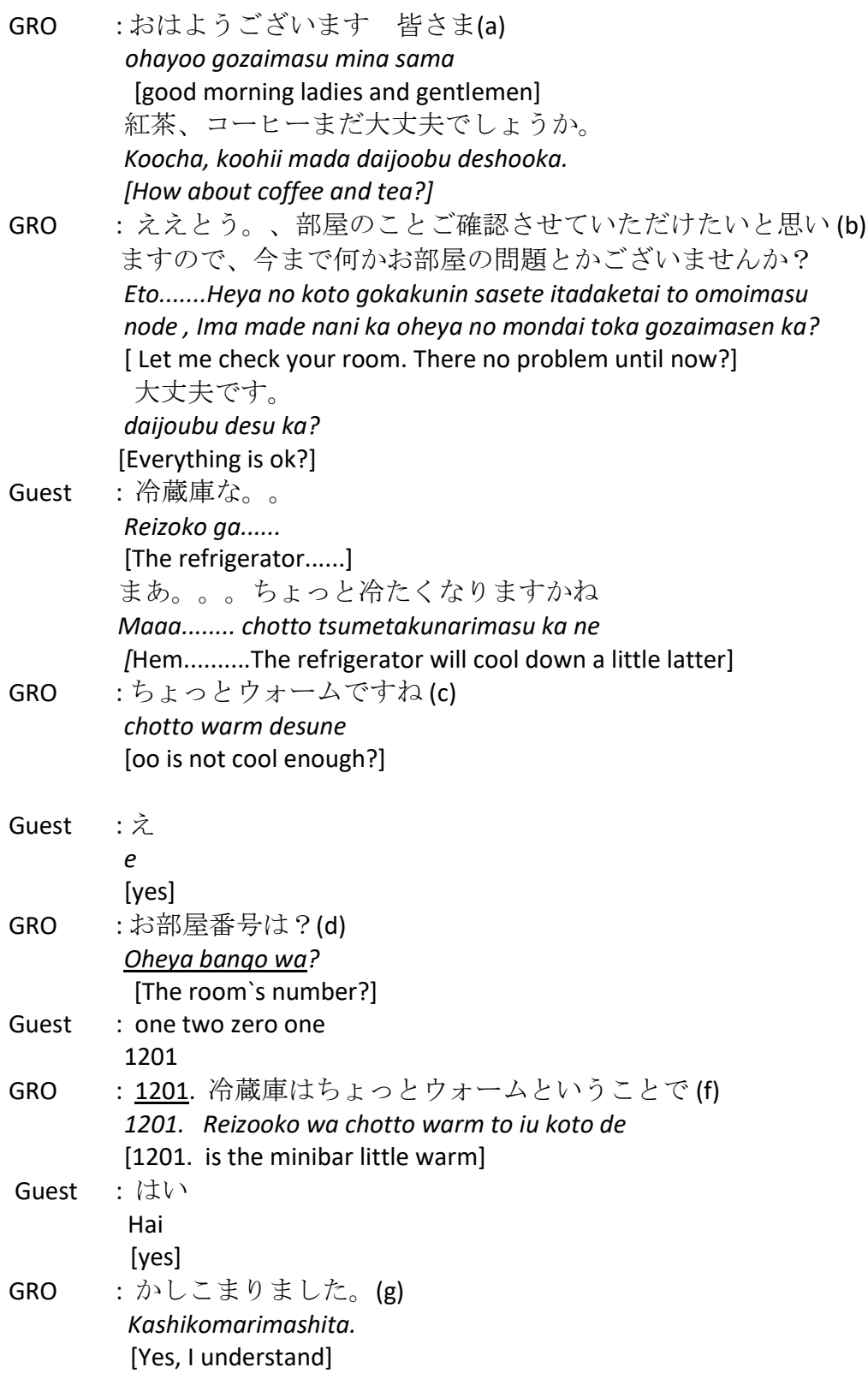


GRO

\author{
：あとでうちのスタッフにご確認いたしますので (h) \\ Atode uchi no sutaffu ni gokakunin itashimasu node \\ [ I will confirm to our staff later] \\ もし何かほかの問題がございました私がフロントにおりま \\ すのでお越しいただければ(i) \\ Moshi nanika hoka no mondai ga gozaimashitara, Watashi ga \\ furonto ni orimasu node, okoshi itadakereba...... \\ [if there any problems, I am in front of the desk..if you want to come....]
}

The data above is a conversation between GRO staff and Japanese guests who are enjoying breakfast. This is a formal situation. Guests stay for the third day. When starting the conversation, GRO staff greeted "ohayoo gozaimasu" (good morning). In this context GRO staff began to use a distance approach to guests. This action is a form of positive politeness, with an effort to attract sympathy from guests.

Before getting into the main task of asking guests' about their problems, GRO staff member started by pleasantly asking for the guest's dish "koohii, koocha mada daijoubu deshou ka" (how about the coffee and tea?). An interrogative sentence with the ending " deshou ka?" is a form of Keigo (respectful language). GRO staff member actually wanted to ask and confirm the condition of guests regarding room facilities, food and all their necessities. However GRO staff did not immediately ask "is there a problem with your room?" But begins by asking for coffee or tea. Even though guests are actually enjoying a meal, not drinking coffee or tea. The style of speaking that is not directly to the point of discussion is the style of speaking of Japanese society in general. And this has been implemented by GRO staff. After that, they just get into the topic of conversation. "Heya no koto gokakunin sasete itadaketai to omoimasu node ...." (Please allow us to confirm the state of your room). The markers of politeness are seen in the pattern "verb + sasete itadaketai" (let us do this). The " sasete itadakimasu" pattern is a form of kenjougo (humble language). The word "itadakimasu" comes from the verb morau or kureru which means to accept. The sign of politeness can also be seen in the verb "gokakunin" (confirm). The verb pattern "go + verba3 + itashimasu" is one way of using the variety of Kenjyougo. In the utterance "Heya no koto gokakunin sasete itadaketai to omoimasu node ...", GRO staff used negative politeness; there was a formality in the speech when viewed from the sentence structure. In the GRO speech when they were confirming the guest complaints using the the utterance "chotto warm desu ne" has been applied positive politeness, with the characteristic use of the particle "ne". The speech has applied a positive politeness sub strategy 5 (speakers seeks hearers approval on a topic). Then, the guest responds with the answer "ee" (yes), the informal form of "hai" (yes).

The changes in various languages were seen when GRO staff asked for guest room numbers, "Oheya bango wa?" (your room number?) without the question word "namban desu ka?" , but with a rising tone at the end of the sentence. Judging from the sentence structure, this speech is an incomplete sentence. Judging from the variety of languages, this speech is a variety of futsugo. in Japanese language the utterance without the question word (gimonshi) characterizes the use of the informal style ( futsugo). Whereas from the beginning of the conversation, GRO staff used a variety of Keigo. The futsugo marker is also found when GRO confirms the guest's room number, and data (f). GRO staff repeated the guest answer with the speech "one two zero one" without being followed by the copula desu.

After getting the guest room's data and the problem, GRO staff assured the guest with the answer "Kashikomarimashita" (alright). This utterance uses formal speech. Kashikomarimashita is the formal form of wakarimashita. The meaning of this speech also provides an idea that the staff understands the complaints submitted by guests. In addition, it indicates that the staff will do something so that guests feel calm. The staff then gave an explanation of the corrective action with the speech "Atode uchi no sutaffu ni gokakunin itashimasu node ....." (I will check back later to our staff). This speech denotes that it has implemented a positive politeness sub strategy 10 ( $\mathrm{Pn}$ made a promise that was profitable for hearers/addressee). This is intended to give guests a sense of comfort, peace that there will be maintenance staff who will repair the mini-bar.

Before leaving the guest, GRO reassures the guest to come to the front desk, if there are other problems: "Moshi nanika hoka no mondai ga gozaimashitara, Watashi ga furonto ni orimasu node ......" (if there are other problems, I'm at the front desk .....). In terms of the meaning and purpose of the speech, a positive politeness sub strategy 15 has been implemented (speakers gives attention to hearers), which is offering willingness; willingness to help if guests have problems. The utterance "okoshi itadakereba" (if you wish to come) uses the marker of kenjyougo politeness. The staff did not use the direct speech "doozo furonto ni okoshikudasai" (please come to the front desk) but preferred the speech, "if you please to come". This speech has implemented sub-strategy negative politeness 4 (speakers reduce compulsive speech but give hearers/addressee a choice).

From the conversation in data 1, it can be said that GRO staff at the beginning of the conversation used positive politeness, namely an expression of concern for the guest by greeting and asking about the guest's problems. At the end of the 
conversation, a positive politeness was also shown, namely with the element of attention, and empathy towards the guests. In the content of the discussion, there are two kinds of politeness strategies, namely negative politeness and positive politeness. A positive politeness strategy can be seen from the use of informal forms embodied in the futsugo variety, especially the utterance when confirming the problem of the guest's room.

\section{Data 2.}

Topik : Wasuremono (lost and found)

The interactants:

GRO : 48 years old/female ( Padma Bali hotel)

Guest : 26 years old/female, First coming guest

Guests stay in the third day (day 3)

The context of the speech situations: a female guest with her child approached GRO's table. She said that her son 's hat was left in the tour safari car that had just taken them back to the hotel.

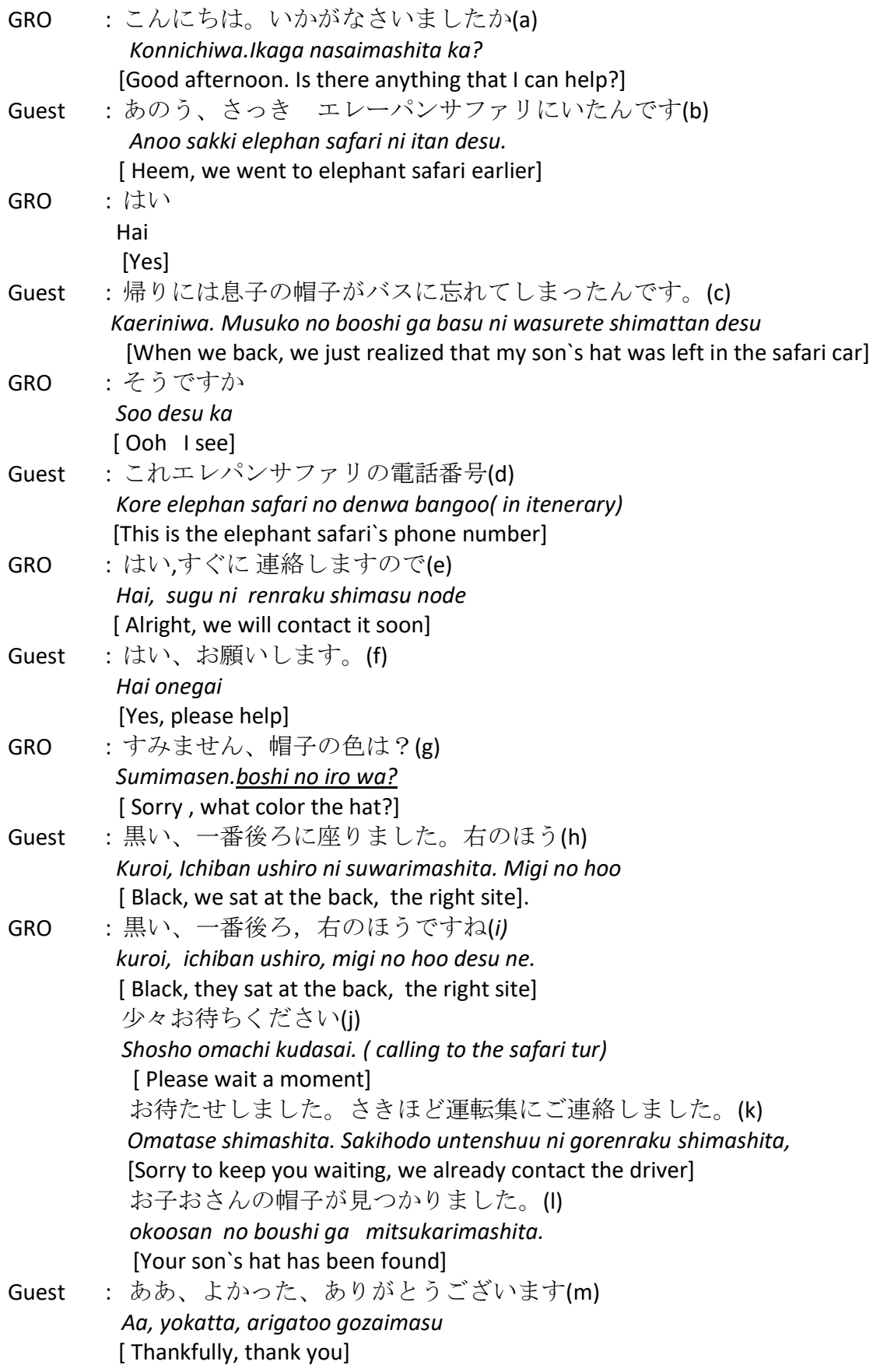




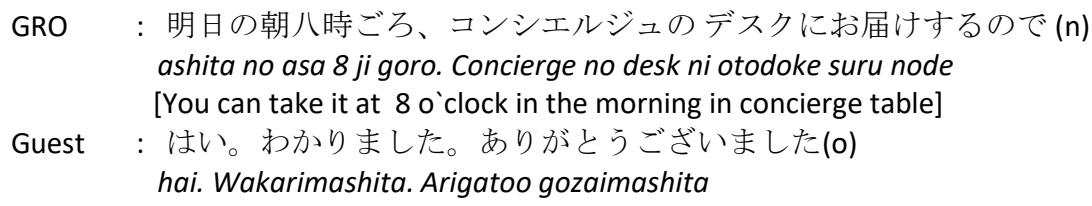

[Yes, I see. Thank you]

The above data (data 2) is a conversation between guests and GRO staff, the situation in the afternoon, the guest returns from a trip to the safari elephant. The young mother guest said that her child's hat had been left in the tour safari elephant car that had just taken them back to the hotel. Based on the structure of the conversation, GRO staff started the conversation with a greeting. In this context GRO staff started to use positive politeness strategy, as an effort to reduce distance from guests. Followed by the offer of help "Ikaga nasaimashita ka?" (Is there anything that I can help?). This strategy is used by GRO staff in an effort to bring attention to guests by offering assistance. In general, tourism workers who always show proactive action pay attention to guests through using formal sentence structure as seen from the beginning of the conversation. When the guest delivered the chronology of the incident, the staff listened more and gave short responses, such as "hai" (yes), "soo desu ka" (oo I see). Short responses are known as "aizuchi". Aizuchi is a sign of politeness. For Japanese people, aizuchi is one of the norms in communicating. Without Aizuchi, listeners are not considered to listen seriously and do not show respect of the speaker.

In the content section of the conversation, which is when confirming guest problems, it is found that the structure changes from formal to informal. "Sumimasen, boushi no iro wa?" (sorry, the color of the hat?) is spoken in an upward tone, without question. The staff asked for the color of the hat in a short utterance with a sentence that didn't finish until the end. Short utterance without "desu" characterizes the use of futsugo (informal form). The futsugo style is one of the characteristics of a positive politeness strategy. In speech (j) to (o), the sentence structure returned to be formal. After it was confirmed that the hat problem was left in the car and got the answer that it would be delivered to the hotel on the next day, the staff returned to using formal utterance (negative politeness) until the end of the conversation.

If we analyzed, the data above, it can be observed that the staff used a futsugo, a type of short utterance when confirming guest problems. If we analyzed, why does staff use short utterance in the form of futsugo? It is possible to do this with the following considerations: 1) the reason for the practicality of communication, 2) the short speech is easy to catch the ear, 3) shows that the staff understands what the guest complained about, 4) accelerates the resolution of guest complaints.

As seen in the analyzed data, it is seen that informal style can be accepted in the hospitality industry services, especially the utterances that are related to the resolution of guest complaints. When viewed as a whole in one dialogue, GRO staff have implemented a politeness strategy, it can be seen from the utterance that contain elements of attention and respect for guests.

The research related to the language of hospitality has been conducted by Blue \& Harun (1998). By adopting the theory of "guest cycle in the hotel" from Kasavana (1993). Blue \& Harum identify language used in service into four stages, namely (1) arrival, (2) familiarisation (3) engagement and (4) departure.

When viewed from this stage, the dialogue above is a dialogue at the engagement stage, where guests stay at the hotel on the third or fourth day. At the engagement stage, the relationship between guests and staff is less rigid than at the beginning of the meeting. They have started to know each other. So if in communication there are formal and informal speech mixed in one dialogue, it can be considered normal. Even so, it does not matter if the staff uses informal speech. It's different when the dialogue is at the arrival stage, like this conversation.

Topic: pick up the guest at the airport

The interactants:

Airport Representative (AR): 53 years old/man ( Four Seasons hotel)

Guest $(G) \quad$ : a couple of husnband and wife, 45 years old

The first meeting

AR ：すみません。田中様でしょうか

Sumimasen, Tanaka-sama deshou ka?

[ Excuse me, are you Mr. Tanaka?]

G

: はい

yes

AR : フォシーズンホテルのお客様でしょうか

Four Seasons hoteru no okyakusama deshou ka

[Are you the guest of Four Seasons hotel?]

G ：はい、そうです

Hai, soo desu 
[Yes, I am]

AR ：バリへいらっしやいませ。はじめまして、フォシーズンホ テルフォシーズンホテルのワ

ワンと申します。どうぞよろしくお願いします。

Bali e irasshaimase. Hajimemashite, Four seasons hoteru no Wawan to mooshimasu. Doozo

yoroshiku onegashimasu.

[Welcome to Bali. My name is Wawan, I am staff of Four Seasons hotel, Nice to meet you]

G

: よろしくお願いします

Yoroshiku onegai shimasu

[Nice to meet you to]

AR

: お荷物はそろていますか。お持ちしましょうか。どうぞこちらへ

Onimotsu wa soroteimasu ka. Omochi shimashou ka. Doozo kochira e

Your luggege is complete? Let'us bring your luggage. This way please

G

: はい

hai

ok

In the above data, it can be noticed that from the beginning of the conversation towards its end, Futsugo's utterance was not found. It can be understood that at the arrival stage, the imposition rank is high. The Airport representative and guests are meeting for the first time. Staff use honorific language, to show the respect to the guests. Usually, Japanese guests use Teineigo with people they have just met as a neutral, polite language.

Research on Japanese politeness in the tourism domain has been carried out by Dian (2019). One of the results of her dissertation states that futsugo utterances are mostly found in the context of informal conversations. However, in formal places such as hotel lobbies, travel agent offices do not find conversations containing Futsugo's utterances. The following is a futsugo story found in the dialogue between tourists and beach boys on the beach.

\begin{tabular}{|c|c|}
\hline Beach boy & $\begin{array}{l}\text { : おはようございます社長さん } \\
\text { Ohayou gozaimasu. Shachou san. } \\
\text { [Good morning, sir.] }\end{array}$ \\
\hline Tourist & : (silent, nothing answer) \\
\hline Beach boy & $\begin{array}{l}\text { サーフィンぐやらない? } \\
\text { Safinngu yaranai??. } \\
\text { [Do you want to surfing?] }\end{array}$ \\
\hline Tourist & $\begin{array}{l}: ノ \\
{[\mathrm{No}]}\end{array}$ \\
\hline Beach boy & $\begin{array}{l}\text { : みつあみ、マッサージは? } \\
\text { Mitsuami, massa-ji wa? } \\
\text { [ offer hair braid or massage] }\end{array}$ \\
\hline
\end{tabular}

From the conversation above, it can be seen that the beach boy uses a formal speech at the beginning of the conversation by greeting tourists. However, in the next dialogue an informal utterance, in the form of futsugo, is used. So, from Dian's research, it was found that place, and speakers influence language choice. If the speaker is a tourism worker who works in the formal sector, such as hotels, airports, travel agentcies, tourist information outlets, then formal language ( Keigo) is used. If the speakers are sellers of services who work in the informal sector, such as surf rental services, surf coaches, souvenir sellers, braids, people who do massage, then the utterance found is informal (futsugo).

\section{Conclusion}

Futsugo style can be used in the situation of hotel services where formal speech is generally used. According to the analyzed data, it can be said that the Futsugo style was found when the hotel staff confirmed guest complaints/problems. After getting clear on the important points needed to solve guest problems, the staff returned to using formal speech with a variety of Keigo. If we analyzed why staff use short speech in the form of Futsugo, it is probably due to the following considerations: 1) the reason for the practicality of communication, 2) the short speech is easy to catch by the ear, 3) shows that the staff understands what guests are saying and complaining about, 4) accelerating the resolution of guest complaints.

When viewed from the theory of "guest cycle in hotel", the dialogue containing Futsugo's words is found at the engagement stage. At the arrival stage, no Futsugo style was found. The reason maybe that at the arrival stage, the imposition rank was still high, so staff were very careful in choosing words and speech forms. However, at the engagement stage, guests and staff have already started to get to know each other. Moreover, guests are now able to adapt to the hotel environment, including hotel 
staff, so that if there is informal speech mixed with formal speech it can still be accepted by the guest (do not threaten guests' faces).

Funding: This research received no external funding.

Acknowledgments: The writer would like to thank and appreciate those who have contributed to this current study, especially the supervisors: Prof. Dr. I Wayan Simpen, M.Hum.; Prof. Dr. Made Budiarsa, M.A.; Prof. Dr. I Ketut Darma Laksana,M.Hum. For their crititicism, comments and suggestions. Thanks also expressed to my best friend Suparman for the translation

\section{References}

[1] Brown, P.\& Levinson, S. (1978). Politeness: Some Universals in Language Usage. Cambridge University Press

[2] Blue, G.M \& Harun, M. (2003). Hopitality language As A Profesional Skill. English for Special Purpose 22,73-91

[3] Backhaus, P. 2009. Politeness in Institutional Elderly in Japan: A Cross Cultural Comparison. Journal of Politeness Research (5). 53-71.

[4] Bagyono. (2012). Teori dan Praktek Hotel Front Office. Bandung:Alfabeta.

[5] Dian, A. A. (2019). The Gradation and Strategy Shifting of Language Politeness toward Japanese Tourists in Bali (Dissertation). Semarang : Universitas Sebelas Maret

[6] Ide, S. (1982). Japanese sociolinguistics politeness and women's language. Lingua, 57(2-4), 357-385.

[7] Kikuchi, Y. (1996). Keigo Nyuumon. Maruzen.

[8] Kabaya, H. (2009). Keigo Hyougen. Taishukan.

[9] Kaneko, H. (2014). Nihongo Keigo Toreeninggu. PT Ask.in Japanese.

[10] Merlyana, D. (2019). Kesantunan Berbahasa Jepang Caregiver Indonesia terhadap Lansia di Jepang (Dissertation). Denpasar: Universitas Udayana

[11] Merlyana, D. (2019). Shift of Politeness Strategy made by The Indonesian Caregivers in Japan International. Journal of Linguistics, Literature and Translation, 2(1). 245-255

[12] Takiura, M. (2008). Poraitonesu Nyuumon. Kenkyusha

[13] Usami, M. (2002). Discourse Politeness in Japanese Conversation : Some Implications for a Universal Theory of Politeness. Tokyo : Hitsushi Shobo 